\title{
PENGUKURAN VALUE AT RISK PADA ASET TUNGGAL DAN PORTOFOLIO DENGAN SIMULASI MONTE CARLO
}

\author{
Di Asih I Maruddani ${ }^{1}$, Ari Purbowati ${ }^{2}$ \\ ${ }^{1}$ Staf Pengajar Program Studi Statistika FMIPA UNDIP \\ ${ }^{2}$ Biro Pusat Statistika Jakarta
}

\begin{abstract}
Value at Risk (VaR) is the established standard for measuring market risk. VaR measures the worst expected loss under normal market conditions over a specific time interval at a given confidence level. A VaR statistic has three components: a time period, a confidence level and a loss amount (or loss percentage). The Monte Carlo simulation method calculates the change in the value of positions by using a random sample generated by price scenarios. Instead of using the past value of risk factors, Monte Carlo simulation generates models to estimate the risk factors from past portfolio returns by specifying the distributions and their parameters. Using these distributions and parameters, we can generate thousands of hypothetical scenarios for risk factors and, finally, we can determine future prices or rates based on hypothetical scenarios. VaRs can be derived from the cumulative distribution of future prices or rates for given confidence levels. In this paper, we calculate VaR at PT Astra International Tbk., PT Telekomunikasi Tbk., and the portfolio of the two assets. PT. Astra International Tbk has higher VaR than PT. Telekomunikasi Tbk. The VaR of a portfolio has lower result than $\mathrm{VaR}$ of each single asset.
\end{abstract}

Keywords : Value at Risk, Time Period, Confidence Level, Monte Carlo Simulation.

\section{Pendahuluan}

Salah satu paradigma penting pada manajemen risiko dalam mengelola risiko adalah bahwa risiko dapat didekati dengan menggunakan suatu kerangka pikir yang sangat rasional. Analisis risiko yang didalamnya banyak memanfaatkan metode statistika sangat berperan dalam menentukan ukuran risiko yang merupakan elemen penting dalam manajemen risiko.

Penerapan metode Value at Risk (VaR) merupakan bagian dari manajemen risiko. $V a R$ pada saat ini banyak diterima, diaplikasikan dan dianggap sebagai metode standar dalam mengukur risiko. $V a R$ dapat didefinisikan sebagai estimasi kerugian maksimum yang akan didapat selama periode waktu (time period) tertentu dalam kondisi pasar normal pada tingkat kepercayaan (confidence level) tertentu ${ }^{[6]}$. Secara sederhana, VaR ingin menjawab pertanyaan "seberapa besar (dalam persen atau sejumlah uang tertentu) investor dapat merugi selama waktu investasi t dengan tingkat kepercayaan $(1-\alpha)^{\text {, }[4]}$. Investor dapat menggunakan nilai $V a R$ sebagai salah satu tolok ukur dapat menetapkan seberapa besar target risiko.

Aspek terpenting dalam perhitungan $V a R$ adalah menentukan jenis metodologi dan asumsi yang sesuai dengan distribusi return. Hal ini dikarenakan perhitungan VaR berdasarkan pada distribusi return sekuritas. Penerapan metode dan asumsi yang tepat akan menghasilkan perhitungan $V a R$ yang akurat untuk digunakan sebagai ukuran risiko.

Ada tiga metode utama untuk menghitung $V a R$ yaitu metode parametrik (disebut juga metode varian-kovarian), metode simulasi Monte Carlo dan simulasi historis. Ketiga metode mempunyai karakteristik dengan kelebihan dan kekurangannya masing-masing. Metode varian-kovarian mengasumsikan bahwa return berdistribusi normal dan return portofolio bersifat linier terhadap return aset tunggalnya. Kedua faktor ini menyebabkan estimasi yang lebih rendah terhadap potensi volatilitas aset atau portofolio di masa depan. VaR dengan metode simulasi Monte Carlo mengasumsikan bahwa return berdistribusi 
normal yang disimulasikan dengan menggunakan parameter yang sesuai dan tidak mengasumsikan bahwa return portofolio bersifat linier terhadap return aset tunggalnya. VaR dengan simulasi historis adalah metode yang mengesampingkan asumsi return yang berdistribusi normal maupun sifat linier antara return portofolio terhadap return aset tunggalnya.

Pada tulisan ini, akan dibahas perhitungan VaR dengan menggunakan metode simulasi Monte Carlo. Metode ini merupakan metode yang paling kuat untuk mengukur VaR karena dapat menghitung bermacam-macam susunan eksposur dan risiko meliputi risiko harga nonlinier, risiko volatilitas, dan risiko model tetap. Metode ini juga cukup fleksibel untuk menggabungkan variasi waktu pada volatilitas, fat tails dan skenario yang ekstrim. Simulasi dapat membangkitkan seluruh fungsi kepadatan peluang, tidak hanya satu kuantil dan dapat digunakan untuk menentukan ekspektasi kerugian yang melampaui nilai $V_{a R}{ }^{[6]}$. Dalam mengestimasi nilai $V a R$, metode simulasi Monte Carlo melakukan simulasi dengan membangkitkan bilangan random berdasarkan karakteristik dari data yang akan dibangkitkan, yang kemudian digunakan untuk mengestimasi nilai VaR-nya.

\section{Bahan dan Metode}

\subsection{Bahan}

Penelitian dilakukan pada saham PT. Astra International Tbk (ASII) dan PT. Telekomunikasi Indonesia Tbk (TLKM), serta portofolio dari kedua perusahaan tersebut. Software yang digunakan untuk membantu analisis adalah Microsoft Excel dan R.

Data yang digunakan untuk perhitungan VaR dengan metode simulasi Monte Carlo pada aset tunggal dan portofolio adalah data return yang diperoleh dari perhitungan harga penutupan (closing price) saham harian dari PT. Astra International Tbk (ASII) dan PT. Telekomunikasi Indonesia Tbk (TLKM) selama satu tahun perdagangan (246 hari kerja) yaitu mulai 2 Januari 2007 sampai 28 Desember 2007. Return diasumsikan independen untuk setiap periode waktu. Data diambil dari Bursa Efek Indonesia $(\mathrm{BEI})^{[7,8]}$.

\subsection{Metode}

\subsubsection{Return}

Return dari suatu aset adalah tingkat pengembalian atau hasil yang diperoleh akibat melakukan investasi ${ }^{[9]}$. Return merupakan salah satu faktor yang memotivasi investor untuk berinvestasi karena dapat menggambarkan secara nyata perubahan harga. Return pada waktu ke- $t$ dinotasikan dengan $R_{t}^{[6]}$.

Return $\left(R_{t}\right)$ didefinisikan sebagai berikut

$$
R_{t}=\ln \left(1+R_{t}\right)=\ln \left(\frac{S_{t}}{S_{t-1}}\right)=\ln \left(S_{t}\right)-\ln \left(S_{t-1}\right)
$$

dengan $S_{t}$ adalah harga aset pada waktu ke- $t$ tanpa adanya dividen

\subsubsection{Risiko}

Secara umum, risiko adalah tingkat ketidakpastian akan terjadinya sesuatu atau tidak terwujudnya sesuatu tujuan, pada suatu kurun atau periode waktu tertentu (time

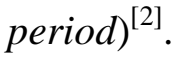

Dalam bidang finansial, risiko sering dihubungkan dengan volatilitas atau penyimpangan/deviasi dari hasil investasi yang akan diterima dengan keuntungan yang diharapkan. Volatilitas merupakan besarnya harga fluktuasi dari sebuah aset. Semakin besar volatilitas aset, maka semakin besar kemungkinan mengalami keuntungan atau kerugian. Van Horne dan Wachowics, Jr (1992) mendefinisikan risiko sebagai variabilitas 
(keragaman) return terhadap return yang diharapkan ${ }^{[5]}$. Investor yang rasional akan cenderung memilih aset investasi yang mengandung risiko yang lebih rendah.

Jika terdapat $\mathrm{n}$ (jumlah observasi) return, maka ekspektasi return dapat diestimasi dengan rata-rata sampel (mean) return

$$
\bar{R}_{t}=\frac{1}{n} \sum_{t=1}^{n} R_{t}
$$

Return rata-rata kemudian digunakan untuk mengestimasi varian tiap periode yaitu kuadrat standar deviasi per periode

$$
S^{2}=\frac{1}{n-1} \sum_{t=1}^{n}\left(R_{t}-\bar{R}_{t}\right)^{2}
$$

disebut varian per periode karena besarnya tergantung pada panjang waktu ketika return diukur. Akar dari varian (standar deviasi) merupakan estimasi risiko dari harga saham yaitu

$$
S=\sqrt{\frac{\sum_{t=1}^{n}\left(R_{t}-\bar{R}_{t}\right)^{2}}{n-1}}
$$

Standar deviasi tahunan (volatilitas tahunan) dapat diestimasi sebagai berikut

$$
S=\sqrt{\text { jumlah hari perdagangan } \frac{\sum_{t=1}^{n}\left(R_{t}-\bar{R}_{t}\right)^{2}}{n-1}}
$$

\subsubsection{Portofolio}

Portofolio adalah gabungan dua atau lebih sekuritas yang terpilih sebagai target investasi dari investor pada kurun waktu tertentu dengan suatu ketentuan tertentu, misalnya mengenai proporsi pembagian dana atau modal yang ditanamkan.

Return dari portofolio dapat ditulis dengan persamaan

$$
R_{p, t}=\sum_{i=1}^{N} w_{i} R_{i, t}
$$

dimana

$$
\begin{aligned}
\mathrm{N} & =\text { banyaknya aset dalam portofolio } \\
R_{i, t} & =\text { return aset ke-i pada periode ke- } \mathrm{t}
\end{aligned}
$$

$w_{i}=$ besarnya komposisi atau proporsi aset ke-i dalam portofolio, dengan $\sum_{i=1}^{N} w_{i}=1$

Dalam bentuk notasi matriks, return portofolio pada waktu $t$ dapat ditulis sebagai berikut

dimana

$$
R_{p}=w_{1} R_{1}+w_{2} R_{2}+\ldots+w_{N} R_{N}=\left[\begin{array}{lll}
w_{1} & w_{2} \ldots w_{N}
\end{array}\right]\left[\begin{array}{c}
R_{1} \\
R_{2} \\
\vdots \\
R_{N}
\end{array}\right]=\mathbf{w}^{T} \mathbf{R}
$$

$$
\begin{aligned}
& \mathbf{w}^{T}=\text { vektor transpose (horisontal) dari } w_{i} \\
& \mathbf{R}=\text { vektor vertikal yang terdiri dari return aset tunggal }
\end{aligned}
$$


Nilai ekspektasi dari return portofolio adalah

$$
E\left(R_{p}\right)=\mu_{p}=\sum_{i=1}^{N} w_{i} \mu_{i}
$$

dan variannya adalah

$$
\begin{aligned}
\operatorname{Var}\left(R_{p}\right)=\sigma_{p}^{2} & =\sum_{i=1}^{N} w_{i}^{2} \sigma_{i}^{2}+\sum_{i=1}^{N} \sum_{j=1}^{N} w_{j} w_{j} \sigma_{i j} \\
& =\sum_{i=1}^{N} w_{i}^{2} \sigma_{i}^{2}+2 \sum_{i=1}^{N} \sum_{j<i}^{N} w_{i} w_{j} \sigma_{i j}
\end{aligned}
$$

dengan $\mu_{i}=$ nilai ekspektasi dari aset ke- $i$

$$
\begin{aligned}
& \sigma_{i}^{2}=\text { varian dari aset ke- } i \\
& \sigma_{i j}=\text { kovarian. }
\end{aligned}
$$

Dalam bentuk notasi matriks, nilai ekspektasi dan varian dari return portofolio dapat ditulis sebagai berikut

$$
\begin{aligned}
& \mu_{p}=w_{1} \mu_{1}+w_{2} \mu_{2}+\ldots+w_{N} \mu_{N}=\left[\begin{array}{ll}
w_{1} w_{2} \ldots w_{N}
\end{array}\right]\left[\begin{array}{c}
\mu_{1} \\
\mu_{2} \\
\vdots \\
\mu_{N}
\end{array}\right]=\mathbf{w}^{T} \boldsymbol{\mu} \\
& \sigma_{p}^{2}=\left[w_{1} \cdots w_{N}\right]\left[\begin{array}{lllll}
\sigma_{11} & \sigma_{12} & \sigma_{13} & \cdots & \sigma_{1 N} \\
\vdots & & & & \\
\sigma_{N 1} & \sigma_{N 2} & \sigma_{N 3} & \cdots & \sigma_{N}
\end{array}\right]\left[\begin{array}{l}
w_{1} \\
\vdots \\
w_{N}
\end{array}\right]=\mathbf{w}^{T} \sum \mathbf{w}
\end{aligned}
$$

dengan $\boldsymbol{\Sigma}$ didefinisikan sebagai matriks varian-kovarian.

Return ekspektasi (expected return) merupakan return yang diharapkan akan diperoleh investor untuk pengambilan keputusan investasi ${ }^{[5]}$. Return ekspektasi dapat dihitung menggunakan nilai ekspektasi dari return.

\subsubsection{Mean Variance Efficient Portofolio (MVEP)}

Dalam pembentukan portofolio, seorang investor berusaha memaksimumkan return yang diharapkan (expected return) dari investasi dengan tingkat risiko tertentu. Dengan kata lain, portofolio yang dibentuk dapat memberikan tingkat risiko terendah dengan return ekspektasi tertentu. Portofolio yang dapat mencapai tujuan tersebut dikenal dengan portofolio yang efisien (efficient portofolio). Dalam pembentukan portofolio efisien, perilaku investor yang wajar terjadi dalam keputusan investasi adalah investor yang cenderung menghindari risiko (risk averse). Investor yang risk averse adalah investor yang jika dihadapkan pada dua investasi dengan return ekspektasi yang sama dan risiko berbeda, maka ia akan memilih investasi dengan tingkat risiko yang lebih rendah. Jika seorang investor memiliki beberapa pilihan portofolio yang efisien, maka portofolio yang optimallah yang akan dipilihnya.

Portofolio yang optimal adalah portofolio yang dipilih seorang investor dari sekian banyak pilihan yang ada pada kumpulan portofolio yang efisien. Tentunya portofolio yang dipilih seorang investor adalah portofolio yang sesuai dengan preferensi investor bersangkutan terhadap return maupun risiko yang bersedia ditanggungnya ${ }^{[1]}$.

Salah satu metode dalam pembentukan portofolio optimal yaitu mean variance efficient portofolio (MVEP). Dalam MVEP investor hanya berinvestasi pada aset-aset 
berisiko saja. Investor tidak memasukkan aset bebas risiko (risk free asset) dalam portofolionya. Sebuah aset dikatakan bebas risiko jika return yang akan diterima di masa depan bersifat pasti. Salah satu contoh aset bebas risiko adalah obligasi yang diterbitkan pemerintah. Untuk kasus di Indonesia, Sertifikat Bank Indonesia (SBI) yang diterbitkan oleh Bank Indonesia merupakan salah satu contoh aset yang bebas risiko.

Mean variance efficient portofolio (MVEP) didefinisikan sebagai portofolio yang memiliki varian minimum diantara keseluruhan kemungkinan portofolio yang dapat dibentuk. Jika diasumsikan preferensi investor terhadap risiko adalah risk averse (menghindari risiko), maka portofolio yang memiliki mean variance efisien (mean variance efficient portofolio) adalah portofolio yang memiliki varian minimum dari mean returnnya. Hal tersebut sama dengan mengoptimalisasi bobot $\mathbf{w}=\left[w_{1} \ldots w_{N}\right]^{T}$ berdasarkan maksimum mean return dari varian yang diberikan.

Secara lebih formal, akan dicari vektor pembobotan $\mathbf{w}$ agar portofolio yang dibentuk mempunyai varian yang minimum berdasarkan dua batasan (constraints) yaitu

1. Spesifikasi awal dari mean return $\mu_{p}$ harus tercapai yaitu $\mathbf{w}^{T} \boldsymbol{\mu}$.

2. Jumlah proporsi dari portofolio yang terbentuk sama dengan 1 yaitu $\mathbf{w}^{T} \mathbf{1}_{N}=1$, dimana $\mathbf{1}_{N}$ adalah vektor satu dengan dimensi $\mathrm{N}$ x 1 .

Permasalahan optimalisasi dapat diselesaikan dengan fungsi Lagrange yaitu

$$
L=\mathbf{w}^{T} \boldsymbol{\Sigma} \mathbf{w}+\lambda_{1}\left(\mu_{p}-\mathbf{w}^{T} \boldsymbol{\mu}\right)+\lambda_{2}\left(1-\mathbf{w}^{T} \mathbf{1}_{N}\right)
$$

dimana $L=$ fungsi Lagrange

$$
\lambda=\text { faktor pengali Lagrange }
$$

Untuk kasus portofolio dengan varian efisien, tidak ada pembatasan pada mean portofolio $\left(\lambda_{1}=0\right)$, sehingga pembobotan pada mean variance efficient portofolio dengan return $\mathbf{X} \sim N_{N}(\boldsymbol{\mu}, \boldsymbol{\Sigma})$ adalah

$$
\mathbf{w}=\frac{\boldsymbol{\Sigma}^{-1} \mathbf{1}_{N}}{\mathbf{1}_{N}{ }^{T} \boldsymbol{\Sigma}^{-1} \mathbf{1}_{N}}
$$

dimana $\boldsymbol{\Sigma}^{-1}=$ invers matriks varian-kovarian

\subsubsection{Diversifikasi}

Diversifikasi berkaitan dengan pembentukan portofolio. Diversifikasi sangat penting bagi investor karena dapat meminiumkan risiko tanpa harus mengurangi return yang diterima. Risiko yang dapat didiversifikasikan adalah risiko yang tidak sistematik yaitu bagian dari risiko sekuritas yang dapat dihilangkan dengan membentuk portofolio. Sekuritas-sekuritas yang mempunyai korelasi lebih kecil dari 1 akan menurunkan risiko portofolio.

\subsubsection{Value at Risk (VaR)}

Value at Risk (VaR) merupakan salah satu bentuk pengukuran risiko yang cukup populer. Hal ini mengingat kesederhanaan dari konsep VaR sendiri namun juga memiliki kemampuan implementasi berbagai metodologi statistika yang beragam dan mutakhir.

$V a R$ dapat didefinisikan sebagai estimasi kerugian maksimum yang akan didapat selama periode waktu (time period) tertentu dalam kondisi pasar normal pada tingkat kepercayaan (confidence interval) tertentu ${ }^{[6]}$. Secara sederhana VaR ingin menjawab pertanyaan "seberapa besar (dalam persen atau sejumlah uang tertentu) investor dapat merugi selama waktu investasi $\mathrm{t}$ dengan tingkat kepercayaan (1- $\alpha)$ ". Berdasarkan 
pertanyaan tersebut, dapat dilihat adanya tiga variabel yang penting yaitu besar kerugian, periode waktu dan besar tingkat kepercayaan.

Pada portofolio, VaR diartikan sebagai estimasi kerugian maksimum yang akan dialami suatu portofolio pada periode waktu tertentu dengan tingkat kepercayaan tertentu. Oleh karena itu, terdapat kemungkinan bahwa suatu kerugian yang akan diderita oleh portofolio selama periode kepemilikan akan lebih rendah dibandingkan limit yang dibentuk dengan VaR. Terdapat kemungkinan bahwa kerugian sebenarnya mungkin dapat lebih buruk, sehingga keterbatasan dari $V a R$ adalah tidak dapat menyatakan apapun tentang seberapa besar kerugian yang benar-benar terjadi dan secara definitif tidak menegaskan kemungkinan kerugian yang paling buruk. $\mathrm{VaR}$ hanya menyatakan kerugian yang mungkin akan diderita pada hari-hari buruk yang cukup buruk. Akan tetapi investor dapat menggunakan nilai $V a R$ sebagai salah satu tolok ukur dapat menetapkan seberapa besar target risiko.

Ada tiga metode utama untuk menghitung $V a R$ yaitu metode parametrik (disebut juga metode varian-kovarian), metode simulasi Monte Carlo dan simulasi historis. Ketiga metode mempunyai karakteristik masing-masing. Metode varian-kovarian mengasumsikan bahwa return berdistribusi normal dan return portofolio bersifat linier terhadap return aset tunggalnya. Kedua faktor ini menyebabkan estimasi yang lebih rendah terhadap potensi volatilitas aset atau portofolio di masa depan. VaR dengan metode simulasi Monte Carlo mengasumsikan bahwa return berdistribusi normal dan tidak mengasumsikan bahwa return portofolio bersifat linier terhadap return aset tunggalnya. VaR dengan simulasi historis adalah metode yang mengesampingkan asumsi return yang berdistribusi normal maupun sifat linier antara return portofolio terhadap return aset tunggalnya.

Secara teknis, VaR dengan tingkat kepercayaan $(1-\alpha)$ dinyatakan sebagai bentuk kuantil ke- $\alpha$ dari distribusi return. VaR dapat ditentukan melalui fungsi kepadatan peluang dari nilai return di masa depan $f(R)$ dengan $R$ adalah tingkat pengembalian (return) aset (baik aset tunggal maupun portofolio) ${ }^{[1]}$. Pada tingkat kepercayaan $(1-\alpha)$, akan dicari nilai kemungkinan terburuk, $R^{*}$, sehingga peluang munculnya nilai return melebihi $R^{*}$ adalah $(1-\alpha)$.

$$
1-\alpha=\int_{R^{*}}^{\infty} f(R) d R
$$

Sedangkan peluang munculnya suatu nilai return kurang dari sama dengan $R^{*}$, $p=P\left(R \leq R^{*}\right)$ adalah $\alpha$.

$$
\alpha=\int_{-\infty}^{R^{*}} f(R) d R=P\left(R \leq R^{*}\right)=p
$$

Dengan kata lain, $R^{*}$ merupakan kuantil dari distribusi return yang merupakan nilai kritis (cut off value) dengan peluang yang sudah ditentukan. Persamaan (13) bersifat fleksibel untuk semua distribusi probabilitas.

Jika $W_{o}$ didefinisikan sebagai investasi awal aset (baik aset tunggal maupun portofolio) maka nilai aset pada akhir periode waktu adalah $W=W_{0}(1+R)$. Jika nilai aset paling rendah pada tingkat kepercayaan $(1-\alpha)$ adalah $W^{*}=W_{0}\left(1+R^{*}\right)$, maka VaR pada tingkat kepercayaan $(1-\alpha)$ dapat diformulasikan sebagai berikut

$$
\operatorname{VaR}_{(1-\alpha)}=W_{o} R^{*}
$$

dengan $R^{*}=$ kuantil ke- $\alpha$ dari distribusi return

Secara umum, $R *$ berharga negatif. 


\subsubsection{Periode Waktu}

Periode waktu yang digunakan di dalam mengukur tingkat risiko yang dihadapi sangat tergantung pada jenis bisnis yang dikerjakan oleh suatu perusahaan. Semakin dinamis pergerakan faktor-faktor pasar untuk suatu jenis bisnis tertentu, semakin singkat periode waktu yang digunakan dalam mengukur tingkat risiko yang dihadapi. Sebagai contoh, bank akan melakukan pemantauan atas tingkat risiko yang dihadapi secara harian, yaitu satu hari, satu minggu (lima hari bisnis) sampai dua minggu (sepuluh hari bisnis), di lain pihak, perusahaan yang mempunyai aset riil seperti investor perusahaan real estate mungkin akan menerapkan periode waktu satu bulan (dua puluh hari), empat bulan bahkan satu tahun untuk melakukan pantauan atas tingkat risiko yang dihadapi.

Ekspektasi return meningkat secara linear terhadap waktu sedangkan volatilitas (standar deviasi) meningkat secara linear dengan akar kuadrat waktu, dapat dijabarkan sebagai

$$
\mu(t)=\mu t \text { dan } \sigma^{2}(t)=\sigma^{2} t \Rightarrow \sigma(t)=\sigma \sqrt{t}
$$

Aturan konversi waktu dalam perhitungan VaR dinyatakan sebagai 'Square root of time rule', sehingga konversi periode waktu dalam perhitungan $V a R$ dapat ditulis sebagai berikut $^{[10]}$

$$
\operatorname{VaR}(t)=\sqrt{t} \operatorname{VaR}
$$

Dengan menggunakan aturan konversi periode waktu, maka perhitungan VaR dengan tingkat kepercayaan $(1-\alpha)$ setelah $t$ period pada Persamaan (14) dapat dinyatakan sebagai berikut

$$
\operatorname{VaR}_{(1-\alpha)}(t)=W_{o} R * \sqrt{t}
$$

dimana $t$ adalah banyak periode waktu.

\subsubsection{Tingkat Kepercayaan}

Menentuan tingkat kepercayaan dalam perhitungan $V a R$ tergantung pada penggunaan $V a R$. Tingkat kepercayaan yaitu probabilitas dimana nilai VaR tidak akan melebihi kerugian maksimum. Penentuan tingkat kepercayaan sangat berperan penting karena dapat menggambarkan seberapa besar perusahaan mampu mengambil suatu risiko dan harga kerugian yang melebihi VaR. Semakin besar tingkat kepercayaan yang diambil, semakin besar pula risiko dan alokasi modal untuk menutupi kerugian yang diambil.

\subsubsection{VaR dengan Metode Simulasi Monte Carlo}

Penggunaan metode simulasi Monte Carlo untuk mengukur risiko telah dikenalkan oleh Boyle pada tahun 1977. Dalam mengestimasi nilai Value at Risk (VaR) baik pada aset tunggal maupun portofolio, simulasi Monte Carlo mempunyai beberapa jenis algoritma. Namun pada intinya adalah melakukan simulasi dengan membangkitkan bilangan random berdasarkan karakteristik dari data yang akan dibangkitkan, yang kemudian digunakan untuk mengestimasi nilai VaR-nya. VaR dengan menggunakan metode simulasi Monte Carlo mengasumsikan bahwa return berdistribusi normal.

\subsubsection{VaR dengan Metode Simulasi Monte Carlo pada Aset Tunggal}

VaR dengan metode simulasi Monte Carlo pada aset tunggal mengasumsikan bahwa return aset berdistribusi normal. Secara umum, algoritma sederhana perhitungan VaR menggunakan metode simulasi Monte Carlo pada aset tunggal adalah sebagai berikut:

1. Menentukan nilai parameter dari return aset tunggal. Return diasumsikan mengikuti distribusi normal dengan mean $\mu$ dan varian $\sigma^{2}$. 
2. Mensimulasikan nilai return dengan membangkitkan secara random return aset tunggal dengan parameter yang diperoleh dari langkah (1) sebanyak $n$ buah sehingga terbentuk distribusi empiris dari return hasil simulasi.

3. Mencari estimasi kerugian maksimum pada tingkat kepercayaan $(1-\alpha)$ yaitu sebagai nilai kuantil ke- $\alpha$ dari distribusi empiris return yang diperoleh pada langkah (2), dinotasikan dengan $R^{*}$.

4. Menghitung nilai $V a R$ pada tingkat kepercayaan $(1-\alpha)$ dalam periode waktu $t$ hari yaitu

$$
\operatorname{VaR}_{(1-\alpha)}(t)=W_{0} R * \sqrt{t}
$$

dimana $W_{0}=$ dana investasi awal aset atau portofolio

$R^{*}=$ nilai kuantil ke- $\alpha$ dari distribusi return

$t$ = periode waktu

Nilai $V a R$ yang diperoleh merupakan kerugian maksimum yang akan diderita oleh aset tunggal..

5. Mengulangi langkah (2) sampai langkah (4) sebanyak $m$ sehingga mencerminkan berbagai kemungkinan nilai $V a R$ aset tunggal yaitu $V a R_{1}, V a R_{2}, \ldots, V a R_{\mathrm{m}}$.

6. Menghitung rata-rata hasil dari langkah (5) untuk menstabilkan nilai karena nilai $V a R$ yang dihasilkan oleh tiap simulasi berbeda.

\subsubsection{VaR dengan Metode Simulasi Monte Carlo pada Portofolio}

VaR dengan metode simulasi Monte Carlo pada portofolio mengasumsikan bahwa return aset-aset pembentuk portofolio berdistribusi normal multivariat. Algoritma sederhana perhitungan $V a R$ menggunakan metode simulasi Monte Carlo pada portofolio adalah sebagai berikut

1. Menentukan nilai parameter untuk variabel-variabel (dalam hal ini adalah return aset) serta korelasi antar variabel. Return aset-aset pembentuk portofolio diasumsikan mengikuti distribusi normal multivariat sehingga parameter yang dibutuhkan diantaranya adalah mean return aset-aset pembentuk portofolio dan matriks variankovarian.

2. Mensimulasikan nilai return dengan membangkitkan secara random return aset-aset yang berdistribusi normal multivariat dengan parameter yang diperoleh pada langkah (1) sebanyak $\mathrm{n}$ buah.

3. Nilai return masing-masing aset pada waktu $t$ yaitu $R_{1, t}$ dan $R_{2, t}$ yang dihasilkan pada langkah (2) digunakan untuk menghitung return portofolio pada waktu $t$ yaitu

$$
\begin{aligned}
R p_{t} & =w_{1} R_{1, t}+w_{2} R_{2, t} \\
\text { dengan } & R_{p, t}=\text { return portofolio pada waktu } t \\
w_{1} & =\text { besarnya komposisi atau proporsi aset ke-1 } \\
w_{2} & =\text { besarnya komposisi atau proporsi aset ke-2 }
\end{aligned}
$$

4. Mencari estimasi kerugian maksimum pada tingkat kepercayaan $(1-\alpha)$ yaitu sebagai nilai kuantil ke- $\alpha$ dari distribusi empiris return portofolio yang diperoleh pada langkah (3) yang dinotasikan dengan $R^{*}$.

5. Menghitung nilai $V a R$ pada tingkat kepercayaan $(1-\alpha)$ dalam periode waktu $t$ hari yaitu

$$
\operatorname{VaR}_{(1-\alpha)}(t)=W_{0} R * \sqrt{t}
$$


Nilai $\operatorname{VaR}$ yang diperoleh merupakan kerugian maksimum yang akan diderita portofolio.

6. Mengulangi langkah (2) sampai langkah (5) sebanyak $m$ sehingga mencerminkan berbagai kemungkinan nilai $V a R$ portofolio yaitu $V a R_{1}, V a R_{2}, \ldots, V a R_{\mathrm{m}}$.

7. Menghitung rata-rata hasil dari langkah (6) untuk menstabilkan nilai karena nilai $V a R$ yang dihasilkan oleh tiap simulasi berbeda.

\section{Hasil dan Pembahasan}

\subsection{Uji Normalitas}

Return diasumsikan berdistribusi normal. Sebelum dilakukan perhitungan VaR, terlebih dahulu dilakukan uji asumsi kenormalan data untuk PT. Astra International Tbk (ASII) dan PT. Telekomunikasi Indonesia Tbk (TLKM) masing-masing menggunakan uji Kolmogorov-Smirnov untuk mengetahui apakah benar return ASII dan TLKM mengikuti distribusi normal ${ }^{[3]}$.

Hipotesis

$\mathrm{H}_{0}$ : data return mengikuti distribusi normal

$\mathrm{H}_{1}$ : data return tidak mengikuti distribusi normal

Statistik Uji

$$
D=\sup _{x}\left|S(x)-F_{o}(x)\right|
$$

Tingkat signifikansi $\quad \alpha=5 \%$

Kriteria Uji

$\mathrm{H}_{0}$ ditolak jika $D>D^{*}(\alpha)$ atau $p$-value $<\alpha$

Nilai $D^{*}(0.05)$ yang diperoleh dari tabel Kolmogorov-Smirnov adalah sebesar 0.0869. Dari hasil perhitungan nilai ekstrim Kolmogorov-Smirnov $(D)$ return ASII adalah sebesar 0.0457 dengan nilai $p$-value sebesar 0.6857. Nilai $D<D^{*}(0.05)$ dan p-value > 0.05 yang berarti $\mathrm{H}_{0}$ diterima. Jadi dapat disimpulkan bahwa data return PT. Astra International Tbk mengikuti distribusi normal.

Nilai ekstrim Kolmogorov-Smirnov (D) return TLKM adalah sebesar 0.0821 dengan nilai $p$-value sebesar 0.07357. Nilai $D<D^{*}(0.05)$ dan $p$-value $>0.05$ yang berarti $\mathrm{H}_{0}$ diterima. Jadi dapat disimpulkan bahwa data return PT. Telekomunikasi Indonesia Tbk mengikuti distribusi normal.

\subsection{Tingkat Kepercayaan dan Periode Waktu}

Tingkat kepercayaan yang digunakan pada perhitungan VaR monte Carlo pada aset tunggal ini adalah 95\%. Periode waktu yang digunakan adalah 1 hari.

\subsection{Perhitungan VaR PT. Astra International Tbk (ASII)}

Berdasarkan uji asumsi dan hasil perhitungan, return ASII berdistribusi normal dengan $\mu=0.002092502$ dan $\sigma^{2}=0.0006337162$ yang dinotasikan dengan return ASII $\sim N(0.002092502,0.0006337162)$. Parameter ini digunakan untuk simulasi VaR Monte Carlo.

Nilai $V a R$ selalu berbeda pada masing-masing simulasi. Hal ini disebabkan oleh perbedaan data random yang dihasilkan. Akan tetapi pada dasarnya memberikan hasil yang tidak berbeda jauh antara satu dengan yang lainnya karena return dibangkitkan dengan parameter yang sama. Salah satu cara untuk mengurangi masalah tersebut yaitu dengan menjalankan banyak simulasi kemudian mengambil nilai rata-ratanya.

Pada tingkat kepercayaan 95\% dengan dua puluh lima kali ulangan, menghasilkan rata-rata nilai VaR yang sebesar -38991032 (tanda - menunjukkan kerugian). Hal ini dapat 
diartikan ada keyakinan sebesar 95\% bahwa kerugian yang akan diderita investor tidak akan melebihi Rp. 38.991.032,00 dalam jangka waktu satu hari setelah tanggal 28 Desember 2007 atau dengan redaksi lain dapat dikatakan ada kemungkinan sebesar 5\% bahwa kerugian investasi pada saham PT. Astra International Tbk sebesar Rp. 38.991.032,00 atau lebih.

\subsection{Perhitungan VaR PT. Telekomunikasi Indonesia Tbk. (TLKM)}

Berdasarkan uji asumsi dan hasil perhitungan, return TLKM berdistribusi normal dengan parameter $\mu=-0.00007966122$ dan $\sigma^{2}=0.0004065061$ yang dinotasikan dengan return TLKM $\sim N(-0.00007966122,0.0004065061)$. Parameter ini digunakan untuk simulasi VaR Monte Carlo.

Jika dana awal yang diinvestasikan pada portofolio yang terdiri dari dua aset yaitu ASII dan TLKM sebesar Rp. 1.000.000.000,00, maka pada tingkat kepercayaan 95\% dengan dua puluh lima kali ulangan, menghasilkan rata-rata nilai VaR yang sebesar -32744534 (tanda - menunjukkan kerugian). Hal ini dapat diartikan ada keyakinan sebesar 95\% bahwa kerugian yang akan diderita investor tidak akan melebihi Rp. 32.744.534,00 dalam jangka waktu satu hari setelah tanggal 28 Desember 2007 atau dengan redaksi lain dapat dikatakan ada kemungkinan sebesar 5\% bahwa kerugian investasi pada saham PT. Telekomunikasi Indonesia Tbk sebesar Rp. 32.744.534,00 atau lebih.

\subsection{Perhitungan $V a R$ dengan Metode Simulasi Monte Carlo pada Portofolio yang Terdiri dari Dua Aset}

\subsubsection{Uji Normal Multivariat}

Sebelum dilakukan perhitungan $V a R$, terlebih dahulu dilakukan uji asumsi kenormalan data untuk mengetahui apakah benar return aset-aset pembentuk portofolio mengikuti distribusi normal multivariat.

Uji dilakukan dengan uji Kolmogorov-Smirnov dengan hipotesis

$\mathrm{H}_{0}$ : Jarak mahalanobis berdistribusi chi-kuadrat dengan derajat bebas $p=2$

$\mathrm{H}_{1}$ : Jarak mahalanobis tidak berdistribusi chi-kuadrat dengan derajat bebas $p=2$

Statistik Uji : $D=\sup \left|S(x)-F_{o}(x)\right|$

Tingkat signifikansi $\quad \alpha=5 \%$

Kriteria Uji : $\mathrm{H}_{0}$ ditolak jika $D>D^{*}(\alpha)$ atau $p$-value $<\alpha$

Nilai $D^{*}(0.05)$ yang diperoleh dari tabel Kolmogorov-Smirnov adalah sebesar 0.0869. Nilai ekstrim Kolmogorov-Smirnov $(D)$ pada output adalah sebesar 0.0696 dengan $p$-value sebesar 0.1861 . Nilai $D<D^{*}(0.05)$ dan $p$-value $>0.05$ yang berarti $\mathrm{H}_{0}$ diterima. Jadi jarak mahalanobis berdistribusi chi-kuadrat, sehingga sampel (return aset-aset pembentuk portofolio) dapat diasumsikan berasal dari populasi normal bivariat.

\subsubsection{Tingkat Kepercayaan dan Periode Waktu}

Tingkat kepercayaan yang digunakan pada perhitungan VaR monte Carlo pada portofolio dengan dua aset ini adalah 95\%. Periode waktu yang digunakan adalah 1 hari.

\subsubsection{Korelasi dan Parameter}

Korelasi yang terbentuk dari penggabungan aset ASII dan TLKM adalah 0.4242234. Dapat dilihat bahwa korelasi antara ASII dan TLKM di bawah 1, sehingga diharapkan terjadi efek diversifikasi yang dapat mengurangi risiko. 
Parameter yang digunakan untuk simulasi VaR Monte Carlo pada portofolio adalah vektor mean dan matriks varian-kovarian, yaitu sebesar $\boldsymbol{\mu}=\left[\begin{array}{c}0.002092502 \\ -0.00007966122\end{array}\right]$ dan $\boldsymbol{\Sigma}=\left[\begin{array}{ll}0.0006337162 & 0.0002153156 \\ 0.0002153156 & 0.0004065061\end{array}\right]$

\subsubsection{Bobot atau Proporsi Portofolio}

Bobot atau proporsi yang diberikan pada masing-masing aset diperoleh dari perhitungan menggunakan metode mean varian efficient portofolio (MVEP). Perhitungannya adalah sebagai berikut

$$
\begin{aligned}
& \boldsymbol{\Sigma}^{-1}=\left[\begin{array}{rr}
1924.301 & -1019.252 \\
-1019.252 & 2999.859
\end{array}\right] \\
& \mathbf{1}_{2}=\left[\begin{array}{l}
1 \\
1
\end{array}\right] \quad \mathbf{1}_{2}{ }^{T}=\left[\begin{array}{ll}
1 & 1
\end{array}\right]
\end{aligned}
$$

Dengan menggunakan Persamaan (13)

$$
\begin{aligned}
\mathbf{w} & =\frac{\boldsymbol{\Sigma}^{-1} \mathbf{1}_{N}}{\mathbf{1}_{N}{ }^{T} \boldsymbol{\Sigma}^{-1} \mathbf{1}_{N}} \\
{\left[\begin{array}{l}
w_{1} \\
w_{2}
\end{array}\right] } & =\frac{\left[\begin{array}{rr}
1924.301 & -1019.252 \\
-1019.252 & 2999.859
\end{array}\right]\left[\begin{array}{l}
1 \\
1
\end{array}\right]}{\left[\begin{array}{ll}
1 & 1
\end{array}\right]\left[\begin{array}{rr}
1924.301 & -1019.252 \\
-1019.252 & 2999.859
\end{array}\right]\left[\begin{array}{l}
1 \\
1
\end{array}\right]} \\
& =\left[\begin{array}{l}
0.3136 \\
0.6864
\end{array}\right] \\
w_{1} & =\text { bobot atau proporsi ASII } \\
w_{2} & =\text { bobot atau proporsi TLKM }
\end{aligned}
$$

Berdasarkan hasil perhitungan bobot atau proporsi yang diberikan pada masingmasing aset yaitu sebesar 31\% untuk PT. Astra International Tbk. (ASII) dan 69\% untuk PT. Telekomunikasi Indonesia Tbk (TLKM). Diasumsikan proporsi portofolio ini tetap selama periode kepemilikan.

\subsubsection{Perhitungan VaR Portofolio}

Jika dana awal yang diinvestasikan pada portofolio yang terdiri dari dua aset yaitu ASII dan TLKM sebesar Rp. 1.000.000.000,00, maka pada tingkat kepercayaan 95\% dengan dua puluh lima kali ulangan, menghasilkan rata-rata nilai VaR sebesar -30308619 (tanda - menunjukkan kerugian). Hal ini dapat diartikan ada keyakinan sebesar 95\% bahwa kerugian yang akan diderita investor tidak akan melebihi Rp. 30.308.619,00 dalam jangka waktu satu hari setelah tanggal 28 Desember 2007 atau dengan redaksi lain dapat dikatakan ada kemungkinan sebesar 5\% bahwa kerugian investasi pada portofolio yang terdiri dari saham ASII dan TLKM sebesar Rp. 30.308.619,00 atau lebih.

$V a R$ portofolio lebih rendah dari $V a R$ aset tunggal. Nilai yang lebih rendah tersebut menunjukkan adanya efek diversifikasi. Diversifikasi bisa terjadi karena efek saling mengompensasi antar aset. Jika satu aset mengalami kerugian, sementara aset yang lain mengalami keuntungan, maka keuntungan dari aset satunya dapat digunakan untuk menutupi kerugian aset lain. Efek diversifikasi ini disebabkan karena korelasi yang rendah 
antar aset. Efek diversifikasi akan semakin bernilai besar (yang berarti bisa menurunkan risiko portofolio lebih jauh) jika korelasi antar aset semakin rendah.

\section{Kesimpulan}

Berdasarkan permasalahan yang dikemukakan dalam Tugas Akhir ini, maka dapat

diambil kesimpulan sebagai berikut

1. Perbedaan nilai Value at Risk (VaR) pada setiap ulangan disebabkan oleh perbedaan hasil dari setiap simulasi yang dijalankan. Akan tetapi diperoleh hasil yang tidak berbeda jauh antara satu dengan yang lainnya karena disimulasikan dengan parameter yang sama. Oleh karena itu untuk menstabilkan hasil diambil nilai rata-ratanya.

2. Pada perhitungan $V a R$ aset tunggal, nilai risiko yang akan ditanggung oleh PT. Astra International Tbk lebih besar dari nilai risiko akan yang ditanggung oleh PT. Telekomunikasi Indonesia Tbk .

3. Berdasarkan perhitungan VaR Monte Carlo baik pada aset tunggal maupun portofolio, dihasilkan nilai VaR pada tingkat kepercayaan 95\% sebesar Rp. 38.991.032,00 untuk PT. Astra International Tbk, Rp. 32.744.534,00 untuk PT. Telekomunikasi Indonesia Tbk dan Rp. 30.308.619,00 untuk portofolio. Semakin besar tingkat kepercayaan yang diambil, maka semakin besar pula risiko yang harus ditanggung dan alokasi modal yang digunakan untuk menutupi kerugian tersebut.

4. VaR portofolio lebih rendah dari VaR masing-masing aset. Hal ini disebabkan oleh efek diversifikasi dimana terjadi efek mengompensasi antar aset sehingga dapat menurunkan nilai risiko. Efek diversifikasi akan semakin bernilai besar jika korelasi antar aset rendah.

\section{DAFTAR PUSTAKA}

1. Abdurrakhman, Buku Ajar Pengantar Statistika Keuangan, Universitas Gajah Mada, Yogyakarta, 2007.

2. Batuparan, D.S., BEI NEWS : Mengapa Risk Management?, Edisi 4, BEI, Jakarta, 2000.

3. Conover, Practical Nonparametric Statistics, John Willey and Son, New York, 2000.

4. Harper, D., Introduction to Value at Risk (VaR), Investopedia, 2004, URL : www.investopedia.com, diakses pada 9 November 2007.

5. Jogiyanto, Teori Portofolio dan Analisis Investasi, Edisi 3, BPFE, Yogyakarta, 2003.

6. Jorion, P., Value at Risk: The New Benchmark for Managing Financial Risk, Second Edition, The McGraw-Hill Companies, Inc. New York, 2002.

7. Laporan Keuangan dan Konsolidasian PT. Astra Intenational Tbk dan Anak Perusahaan 31 Desember 2006 dan 2007, URL : www.idx.co.id, diakses pada 27 Mei 2008.

8. Laporan Keuangan dan Konsolidasian PT. Telekomunikasi Indonesia Tbk dan Anak Perusahaan 31 Desember 2006 dan 2007, URL : www.idx.co.id, diakses pada 27 Mei 2008.

9. Ruppert, D., Statistics and Finance An Introduction, Springer, New York, 2004.

10. Tsay, R.S., Analysis of Financial Time Series, Second Edition, John Willey and Son, New York, 2005. 